\title{
Adding metoclopramide to paroxetine induced extrapyramidal symptoms and hyperprolactinemia in a depressed woman: a case report
}

This article was published in the following Dove Press journal:

Neuropsychiatric Disease and Treatment

I September 2016

Number of times this article has been viewed

\section{Ryohei Igata \\ Hikaru Hori \\ Kiyokazu Atake \\ Asuka Katsuki \\ Jun Nakamura}

Department of Psychiatry, University of Occupational and Environmental Health, Kitakyushu, Japan
Correspondence: Hikaru Hori

Department of Psychiatry, University of Occupational and Environmental Health, I-I Iseigaoka, Yahatanishi-ku, Kitakyushu, Fukuoka 807-8555, Japan

Tel $+8 \mid 93$ 69| 7253

$\mathrm{Fax}+81936924894$

Email hori-h@med.uoeh-u.ac.jp
Abstract: A 54-year-old Japanese woman was diagnosed with major depressive disorder and prescribed paroxetine $20 \mathrm{mg}$ /day. In around May 2013, the patient experienced gastric discomfort, so metoclopramide was prescribed. Beginning on June 4, 2013, the patient was given metoclopramide, $10 \mathrm{mg}$ intravenously, twice per week. On the seventh day after beginning metoclopramide, facial hot flushes, increased sweating, muscle rigidity, and galactorrhea were noted. Extrapyramidal symptoms (EPS) rapidly subsided in response to an intramuscular injection of biperiden. Blood biochemical tests revealed an elevated serum prolactin level of $44 \mathrm{ng} / \mathrm{mL}$. After stopping metoclopramide, EPS disappeared. Serum prolactin level decreased to $15 \mathrm{ng} / \mathrm{mL}$ after 4 weeks. In our case, although no adverse reactions had previously occurred following the administration of metoclopramide, the patient developed EPS and hyperprolactinemia following the administration of this antiemetic in combination with paroxetine. Paroxetine and metoclopramide are mainly metabolized by CYP2D6, and they are inhibitors for CYP2D6. We report a case with EPS and hyperprolactinemia whose plasma paroxetine and metoclopramide level rapidly increased after the addition of metoclopramide. Our experience warrants the issuing of a precaution that adverse reactions may arise following the coadministration of metoclopramide and paroxetine even at their respective standard dose levels.

Keywords: metoclopramide, paroxetine, extrapyramidal symptoms, SSRI, hyperprolactinemia, depression

\section{Introduction}

Selective serotonin reuptake inhibitors (SSRIs) are the first-line antidepressants used in primary care and psychiatric practices. Paroxetine, one of the most potent SSRIs, is widely used in the treatment of depression and is a strong selective CYP2D6 inhibitor. Metoclopramide is a drug with a highly potent antiemetic effect and is considered to cause relatively few adverse reactions. In this report, the extrapyramidal symptoms and hyperprolactinemia occurred in a patient receiving a standard dose of metoclopramide concomitantly with an SSRI for the relief of gastrointestinal symptoms, which were due to the exacerbation of depression.

\section{Case report}

Written informed consent was obtained from the patient to publish this paper. A 54-year-old Japanese woman presented with depressed mood, psychomotor retardation, and loss of interest. She was diagnosed with major depressive disorder according to the Diagnostic and Statistical Manual of Mental Disorders, 4th Edition (DSM-IV-TR) in 2006 and was subsequently prescribed paroxetine $20 \mathrm{mg} /$ day. In around May 2013, 
the patient experienced gastric discomfort and visited the Department of Internal Medicine. Metoclopramide, a drug previously taken by the patient that had caused no adverse reactions, was prescribed, but the symptoms persisted. The depressed mood and psychomotor retardation subsequently worsened to a degree such that they interfered with daily activities. The gastric discomfort also gradually worsened; thus, beginning on June 4, 2013, the patient was given metoclopramide, $10 \mathrm{mg}$ intravenously, twice per week in the outpatient emergency care unit. On the seventh day after beginning metoclopramide, facial hot flushes, increased sweating, muscle rigidity, and galactorrhea were observed. The patient's extrapyramidal symptoms were rated on the Drug-Induced Extra-Pyramidal Symptoms Scale ${ }^{1}$ with a score of 16 . The extrapyramidal symptoms rapidly subsided in response to an intramuscular injection of biperiden. Blood biochemical tests revealed an elevated serum prolactin level of $44 \mathrm{ng} / \mathrm{mL}$. The extrapyramidal symptoms were considered to be because of the coadministration of metoclopramide and paroxetine prescribed for the relief of somatic symptoms, such as gastric discomfort arising from recurrent depression. The patient's depressive symptoms were rated on the Hamilton Rating Scale for Depression ${ }^{2}$ with a score of 19. Metoclopramide was thus discontinued, and the dose of paroxetine was increased to $40 \mathrm{mg} / \mathrm{d}$. Seven days later after stopping metoclopramide, the Drug-Induced Extra-Pyramidal Symptoms Scale score improved to 0. The Hamilton Rating Scale for Depression score also improved to 5 , and the serum prolactin level decreased to $15 \mathrm{ng} / \mathrm{mL}$ after 4 weeks.

\section{Discussion}

Metoclopramide is a drug with a highly potent antiemetic effect and is considered to cause relatively few adverse reactions. Several reports described that metoclopramide caused extrapyramidal symptoms via its inhibitory effect on dopaminergic neurons. ${ }^{3-5}$ In most of these papers, it was speculated that the extrapyramidal symptoms were evoked when the drug was administered in high doses. In our case, however, although no adverse reactions had previously occurred following the administration of metoclopramide, the patient developed extrapyramidal symptoms and hyperprolactinemia following the administration of this antiemetic in combination with paroxetine. Paroxetine is an SSRI that is often prescribed for the management of depression, panic disorder, and obsessive-compulsive disorder. There have been several reports indicating the occurrence of extrapyramidal symptoms due to SSRI administration. ${ }^{6-8}$ The underlying mechanism of these symptoms is thought to be due to excessive serotonin, which exerts an inhibitory effect on nigrostriatal dopaminergic neurons.

Moreover, paroxetine and metoclopramide are mainly metabolized by cytochrome P450 (CYP) 2D6. ${ }^{9}$ Paroxetine is a potent inhibitor for CYP2D6, and metoclopramide is a moderate inhibitor for CYP2D6. We report a case with extrapyramidal symptoms and hyperprolactinemia whose plasma paroxetine and metoclopramide level rapidly increased after the addition of metoclopramide.

In our case, the extrapyramidal symptoms and hyperprolactinemia occurred in a patient receiving a standard dose of metoclopramide concomitantly with an SSRI for the relief of gastrointestinal symptoms, which were due to the exacerbation of depression. Our experience with this patient warrants the issuing of a precaution that adverse reactions may arise following the coadministration of metoclopramide and paroxetine even at their respective standard dose levels.

\section{Disclosure}

The authors report no conflicts of interest in this work.

\section{References}

1. Inada T. Evaluation and diagnosis of drug-induced extrapyramidal symptoms. In: Yagi G, editor. Commentary on the DIEPSS and Guide to Its Usage. Toyko: Seiwa Publishers; 1996:11-60.

2. Hamilton M. Development of a rating scale for primary depressive illness. Br J Soc Clin Psychol. 1967;6(4):278-296.

3. de Ronde MW, Kingma HJ, Munts AG. Severe Parkinsonism due to metoclopramide: the importance of early recognition. Ned Tijdschr Geneeskd. 2013;157(26):A6037. Dutch.

4. Oyewole AO, Adelufosi AO, Abayomi O. Acute dystonic reaction as medical emergency: a report of two cases. Ann Med Health Sci Res. 2013; 3(3):453-455.

5. Moos DD, Hansen DJ. Metoclopramide and extrapyramidal symptoms: a case report. J Perianesth Nurs. 2008;23(5):292-299.

6. Nicholson SD. Extra pyramidal side effects associated with paroxetine. West Engl Med J. 1992;107(3):90-91.

7. Leo RJ. Movement disorders associated with the serotonin selective reuptake inhibitors. J Clin Psychiatry. 1996;57(10):449-454.

8. Schillevoort I, van Puijenbroek EP, de Boer A, Roos RA, Jansen PA, Leufkens HG. Extrapyramidal syndromes associated with selective serotonin reuptake inhibitors: a case-control study using spontaneous reports. Int Clin Psychopharmacol. 2002;17(2):75-79.

9. Desta Z, WU GM, Morocho AM, Flockhart DA. The gastroprokinetic and antiemetic drug metoclopramide is a substrate and inhibitor of cytochrome P450 2D6. Drug Metab Dispos. 2002;30(3):336-343. 
Neuropsychiatric Disease and Treatment

Dovepress

\section{Publish your work in this journal}

Neuropsychiatric Disease and Treatment is an international, peerreviewed journal of clinical therapeutics and pharmacology focusing on concise rapid reporting of clinical or pre-clinical studies on a range of neuropsychiatric and neurological disorders. This journal is indexed on PubMed Central, the 'PsycINFO' database and CAS,

and is the official journal of The International Neuropsychiatric Association (INA). The manuscript management system is completely online and includes a very quick and fair peer-review system, which is all easy to use. Visit http://www.dovepress.com/testimonials.php to read real quotes from published authors.

Submit your manuscript here: http://www.dovepress.com/neuropsychiatric-disease-and-treatment-journal 